\title{
Pathways towards the integration of periurban agrarian ecosystems into the spatial planning system
}

\author{
Marian Simon Rojo ${ }^{1 *}$, Ana Zazo Moratalla ${ }^{1}$, Nerea Moran Alonso ${ }^{1}$ and Veronica Hernandez Jimenez ${ }^{2}$
}

\begin{abstract}
Introduction: The potential of periurban agrarian ecosystems is recognized as one of the cornerstones for improving urban sustainability; however, this potential has been disregarded in spatial planning and decision making. The main goal of the PAEc-SP project was to assess the feasibility of integrating periurban agricultural areas into spatial planning by developing a viable ecosystem services-based methodology.

Methods: The research unfolded along three axes: i) mapping ecosystem services in periurban areas, distinguishing between the current state and the future potential by applying a set of indicators; ii) analyzing the regulatory framework, identifying gaps in the consideration of agrarian ecosystem services; and iii) analyzing the perceptions of these areas held by local actors. Provisioning services (food) are widely recognized by actors and plans, but this leads to weak protection.

Results: Cultural services (identity, recreation) are also recognized by all actors and addressed by local urban planning, though this is not connected to farming practices. Regulating services (CO2 storage, water quality) are barely addressed by spatial planning and actors do not value them either. Supporting services (biodiversity) are mostly associated with natural areas. Most technicians are reluctant to changes, while new farmers and civil society demand a new holistic approach.

Conclusion: The reluctant attitude to change of some actors and the inadequate understanding of ecosystem services, render it imperative to adopt a comprehensive approach through a participatory process of urban planning. Mapping ecosystem services, calculations, and graphs are a valuable communication tool both in discussing the consequences of the loss of agrarian ecosystems with different actors and in planning future scenarios.
\end{abstract}

Keywords: Ecosystem service indicators; Institutional inertia; Land use planning; Participatory mapping; Periurban farming; Rural-urban fringe

\section{Introduction}

The dual vulnerability of periurban agriculture

Periurban $\operatorname{areas}^{\mathrm{a}}$ are dynamic spaces with blurred boundaries, highly influenced by urban interactions. They share qualities both with urban and rural areas, serving as an interface between them (Bryant, 1995; Darly and Torre, 2013). All across the globe agricultural periurban areas usually face the highest urban pressure. From Melbourne (Williams et al., 2005) to Vietnam (Lodder, 2012), it is well-documented how land is diverted from agrarian uses to the development of infrastructure

\footnotetext{
* Correspondence: m.simon@upm.es

'GIAUS (Architecture, Urbanism and Sustainability Research Group), School of Architecture, Technical University of Madrid, Avda. Juan de Herrera s/n., 28040 Madrid, Spain

Full list of author information is available at the end of the article
}

and new residential, commercial, or industrial areas, which tend to disturb agrarian landscapes and social structures (Murdoch and Abram, 1998). In Spain, during the last few decades, the impact of urban sprawl has been especially significant on periurban agrarian spaces (Paul and Tonts, 2005; OSE, 2006).

Periurban agriculture can benefit from its proximity to large urban markets, especially for perishable products (Veenhuizen and Danso, 2007) and multifunctional farming that provides different goods and services (Zasada, 2011). Nevertheless, far too often these expectations are not met and the double vulnerability of periurban agriculture persists. Currently, almost every farmer has to face a general disdain towards the agrarian economic sector, with relatively low incomes, a small share of the GDP, a steadily ageing population, and a 
lack of generational take-over (EC, 2010; Carbone and Subioli, 2008). In the case of periurban farmers, these issues are combined with (and exacerbated by) others arising from their location on the urban fringe. Among them, two should be highlighted: the spatial fragmentation due to the construction of highways and other infrastructures or disturbances by other uses (Antrop, 2000; Hewitt and Hernandez-Jimenez, 2010) and, above all, difficulties competing with more lucrative uses, which leads to uncertainty about the future of their activity in a context of urban expansion (Ay and Napoleone, 2013; Simon Rojo et al., 2012a, b) This leads to direct consequences for the socio-economic agrarian structure such as abandonment of agricultural land and its activity.

This situation is indicative of a lack of recognition of periurban agriculture's potential as one of the cornerstones for improving urban sustainability (Mougeot, 2006; McGregor et al., 2006; van Veenhuizen and Danso, 2007). In economic terms, it can contribute to galvanizing certain local economies, especially when embedded in local food systems (Houston, 2005). In environmental terms, they are connected to the urban metabolism, they can assist in closing resource cycles, and contribute to biodiversity (Moreno Flores, 2007). In social terms, their tangible and intangible heritage is a key factor in the local identity (Plieninger and Bieling, 2012) and a valuable resource for education, training, recreation, and, ultimately, for quality of life (Bell, 1999). Periurban agriculture provides and receives ecosystem services that extend well beyond the provision of food, fiber, or fuel. Some of these services are planned, but most are indirect, unmanaged, and unvalued (Swinton et al., 2007).

\section{Periurban agrarian ecosystems in spatial planning}

Most of the benefits of the ecosystems are not captured in conventional market-based economy analyses (de Groot, 2006) and the paradigm of growth in planning results in little attention being paid to non-urban uses. The economic value of agrarian land is negligible compared to its value once targeted for future urban development. In practice, all periurban land has been considered a land reserve, waiting to be urbanized sooner or later (Matarán Ruiz, 2013). If monetary benefits are paramount, no other use can compete with the expected profits of urban development. The research paper "Land cover by direct and indirect urbanindustrial uses in the region of Madrid (1956-19802005)" reports that in Madrid, the loss of agrarian land as a result of the abandonment of agrarian practices is twice as large as that resulting from urban developments (Naredo and García Zaldívar, 2008).

There is another point of controversy. Even when the agrarian land is protected and classified as nonconstructible, this protection fails to provide the necessary conditions for maintaining an ecological balance (Santos y Ganges et al., 2013). For some species, agrarian areas may work as a link to other ecosystems. However, as Herrera highlights, "currently, integration into the regional system of protection is difficult due to the uniformity of these surfaces, the general absence of hedgerows, and the aggressiveness of many agricultural techniques used today". On the other hand, agrarian systems with small plots (patchwork) and greenery between fields could be integrated into larger green networks (Herrera Calvo, 2013).

In short, the potential of periurban agrarian ecosystems has been disregarded in spatial-environmental planning and decision-making (de Groot, 2006), both at local and regional level.

\section{The PAEc-SP Project}

The main goals of the R\&D national project PAEc-Sp ${ }^{b}$ (Integrating Periurban Agrarian Ecosystems in Spatial Planning) were to assess the feasibility of adapting the ecosystem services (ES) approach to the spatial planning process and to develop a viable methodology to operationalize the integration of periurban agricultural spaces into the spatial planning, thus enhancing its conservation and dynamism. It is also geared at increasing and giving visibility to the benefits that these spaces provide for the entire population, whose involvement for their preservation is essential (Matarán Ruiz, 2013).

As shown in Figure 1, 29 inland Spanish cities with a population of between 50,000 and 350,000 inhabitants were analyzed. Cities located within a metropolitan area, like Madrid, were excluded because of the dynamics that these cities experience on account of their proximity to a metropolis. The changes in land use since 1990 were employed to identify trends in urban pressure and different patterns in urban areas in relation to agrarian ecosystems.

As a second stage, a system of indicators and visual tools was developed to aid the process of understanding,

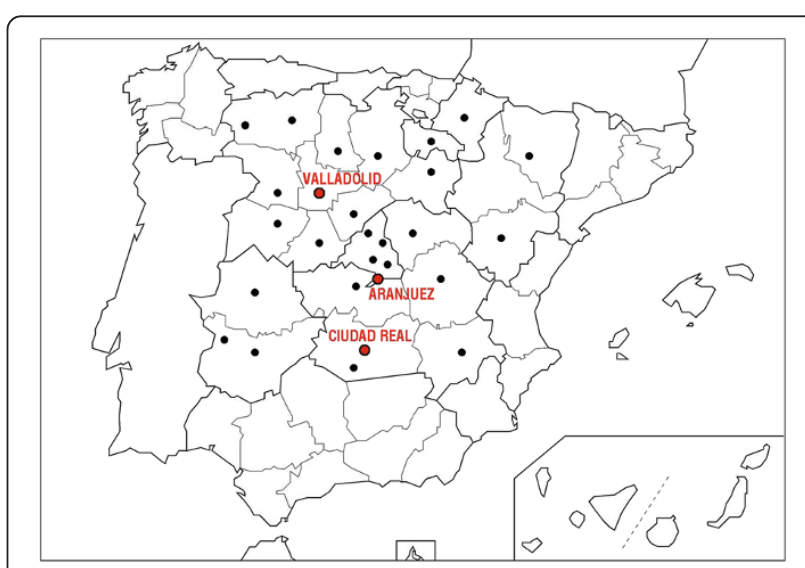

Figure 1 Spanish cities analyzed in the PAEc-Sp project. 
communicating, and assessing the services of these ecosystems with local actors. A major complication is derived from the fact that integrating the ES approach involves introducing new concepts and practices for a wide range of actors. This necessarily implies the disrupting of inertias and the forging of dynamics that will enable technicians, politicians, managers, farmers, and civil society to renew their understanding of periurban agrarian spaces. The innovation of this approach relies on the integration of civil society and local stakeholders as legitimate actors in the process, considering them essential players for the successful design and implementation of spatial plans.

The research focused on three case studies (Aranjuez, Ciudad Real, and Valladolid) in order to test the implementation of the methodology and to evaluate the main constraints of the shift to a new planning approach. The research also explored the perceptions that different stakeholders have of each service, detecting the main difficulties that could hinder the adoption of an integral approach and the factors underlying resistance to change.

\section{Methodological approach}

To achieve the objectives pursued, the project unfolded along three different axes, which are explained in the following sections:

i) Mapping ecosystem services in periurban areas, and the assessment of their provision and trends since the 1980s, by applying a set of indicators.

ii) Analysis of the regulatory framework, spatial plans and local/supra-municipal strategies to identify gaps or imbalances in the consideration of agrarian ES.

iii) Analysis of the actors' perceptions of these periurban areas, as well as understanding their implications in day-to-day management. This would help to assess their awareness of the state and potentials of ecosystem services.

Ultimately, the research described herein compares the findings of these three axes to draw out conclusions and recommendations for future planning processes.

\section{Mapping ecosystem services}

Spatial mapping of ecosystem services provides a better understanding of the complex consequences of private decisions and public policies on the territory (Maes et al., 2013; Crossman et al., 2013; Milleniun Ecosystem Assessment 2003; UK National Ecosystem Assessment 2003; TEEB 2010). In the PAEc-Sp project, these maps constitute the starting point for exploring the state of the ecosystems, recognizing threats and potentials, and discussing future scenarios that can drive policy design and decisionmaking processes with the actors involved. For that reason, the project developed: i) a methodology to identify and map the ecosystems, ii) a set of indicators to assess their services, and iii) a model to visualize ecosystem services and the effects of different spatial decisions

Taking into account the limited economic resources available, the research strategy was based on harnessing the power of existing public, accessible information.

A typology of ecosystems based on the Spanish Millenium Assesment (EME, 2011) was adopted. It includes dryland farming, productive traditional gardens, mosaic, irrigated crops, industrial farming, grasslands, and woody crops (distinguishing also vineyards and olive groves), as well as shrubs and bushes, forest (broadleaf and conifers), riparian vegetation, and water bodies.

To systematize the process of identifying and mapping ecosystems, a GIS tool was developed, based on GIS databases from the Map of Crops and Yields (1985-1998) and the Forestry Map (2000), produced by the Ministry of Agriculture, as well as the EEA's Corine Land Cover Maps (1990, 2000, and 2006). In case of discrepancies between the maps, the tool assigned a priority value according to the reliability of the source layer, e.g., the Map of Crops and Yields in the case of agricultural areas and the Forestry Map in the case of shrubs and forests (Simon Rojo et al., 2012a, b). The results were checked against aerial satellite images to correlate their consistency, which was globally above $80 \%$.

Once the ecosystems were identified, the research strategy was to focus on a reduced number of ES to facilitate future deployment. The criteria to select services were i) that they should be provided by periurban agricultural ecosystems, ii) could be mapped, and iii) their regulation is affected by spatial planning. After analyzing the indicators used for the assessment of the selected services at both National and European levels ${ }^{\mathrm{c}}$, a set of indicators was designed. Usually, ES studies distinguish between the capacity of ecosystems to deliver services and the flows of services and benefits that people receive (expressed in units per time period) (Maes et al., 2011; EME, 2011). Nevertheless, in many cases, accurate information about flows of services is difficult to obtain on a local scale, unless exhaustive field work is conducted. As urban planning defines land use according to the functions of the urban system, a capacity-balance approach was adopted. This approach enables the comparison of the current provision of a service (reference data is 2006) with the future capacity in different scenarios of land use changes.

In order to help planners to understand and apply the ES approach, indicators must provide spatial information and should help in the decision-making process about future land uses. In this regard, spatial scale is one of the core issues to consider. Ecosystem services can be classified according to their spatial characteristics (Costanza, 2008), from those generated on a global scale to those that depend on proximity. A 'too close' local analysis could ignore 
relevant, cross-scale phenomena produced by the interactions between urban, periurban, and regional processes. Data availability and its aggregation scale were a limiting factor.

The selected services are shown in Table 1. Data for indicators were obtained from national public databases, otherwise the homogeneity of information cannot be guaranteed as there are differences between statistics services in the regions. The main sources were the Agricultural Census (2009) and the Population and Housing Census (2011), both conducted every 10 years. The parameters applied to the indicators were based on documented results from well-known institutions and are indicated in Table 1.

Once the set of indicators was fixed, it was applied to each case study, resulting in themed maps. When overlapped, conflicts and synergies between services can be identified. Mapping indicators can help demonstrate ecosystem evolution under different planning scenarios, and this will be developed in a subsequent stage of the project. This is useful for working both with decision makers and the public.

\section{Analysis of spatial plans}

Spatial plans are understood as an expression of public policies and ultimately of the aspirations of society. Discrepancies between the scale of services, policy, and decision-making are well documented (Martín-López et al., 2009; Maes et al., 2011; Martín-López and Montes, 2011). Accordingly, the Spanish hierarchical territorial and urban planning system requires some explanation. The urban planning system in Spain has been divided into three hierarchical levels since the first Land Law came into force in 1956, namely regional planning, which has a greater scope than the municipal level, usually takes the form of guidelines that aim to define the main courses of action; municipal planning or Master plans, which are implemented at a municipal level, incorporate both urban and rural land in a municipality - these documents should comply with regional planning decisions and determine the future uses of land (either to be developed or preserved, depending on the land classification), permitted uses, and building conditions, if applicable, are defined; development planning, which deals with certain pockets of land defined in Master plans - it should comply with Master plan decisions and its main objective is to outline the specific conditions that must be complied with by scheduled developments.

Sectoral plans (for highways, transport, river basins, etc.) are higher ranked documents and prevail over municipal or regional plans. When analyzing the plans in force, a distinction was made between those plans that are binding, such as those which include different forms of environmental protection and their respective management plans, like the Natural Resources Management Plan or the Use and Management Plans or territorial planning documents such as Master Plans, from those that are nonbinding but nevertheless affect the way periurban agricultural land is used, like Agenda 21, Landscape Charters, Local Food Strategies, Rural Development Plans, etc.

The research included both qualitative and quantitative analysis. Qualitative analysis was implemented to identify how agricultural land was dealt with and if there was any

Table 1 Selected indicators for the assessment

\begin{tabular}{|c|c|c|c|c|}
\hline & SERVICE & INDICATOR & DEFINITION & DATA \& METHODOLOGY SOURCE \\
\hline \multirow[t]{2}{*}{ Regulation } & Climate regulation & $\mathrm{CO}_{2}$ storage & Capacity store $\mathrm{CO}_{2}$ (ton/ha) & $\begin{array}{l}\text { OSE (2006) | Emmision data: } \\
\text { Banco Mundial (2012) }\end{array}$ \\
\hline & $\begin{array}{l}\text { Water quality } \\
\text { regulation }\end{array}$ & Groundwater in risk for nitrates & Nitrates' concentration (mg/L) & SIA - MAGRAMA (2008) \\
\hline Provisioning & Food production & $\begin{array}{l}\text { Food production in } \\
\text { irrigated land, dry farming } \\
\text { land, and olive ecosystems }\end{array}$ & $\begin{array}{l}\text { Production capacity } \\
\text { (ton. and inhab. fed) }\end{array}$ & MAGRAMA (2010), SENC (2004) \\
\hline \multirow[t]{2}{*}{ Cultural } & Cultural identity & Heritage opportunity spectrum & $\begin{array}{l}\text { Heritage density* proximity } \\
\text { (gradient) }\end{array}$ & $\begin{array}{l}\text { Protected cultural goods \& space } \\
\text { inventories (Merlos } 2012 \text { and } \\
\text { Aranjuez Local Government 2013). } \\
\text { Maes et al. (2011) }\end{array}$ \\
\hline & Recreation & Recreation opportunity spectrum & $\begin{array}{l}\text { Recreation density* proximity } \\
\text { (gradient) }\end{array}$ & $\begin{array}{l}\text { Recreation info - municipal information } \\
\text { (Aranjuez local government, 2013). } \\
\text { Maes et al. (2011) }\end{array}$ \\
\hline \multirow[t]{2}{*}{ Supporting } & Ecological & UFI (urban fragmentation index) & $\begin{array}{l}\text { Dispersion of urbanization } \\
\text { (gradient) }\end{array}$ & Romano (2002) \\
\hline & Connectivity & Continuity of open spaces & $\begin{array}{l}\text { Density of open spaces referred } \\
\text { to } 1 \mathrm{~km} \text { radius (gradient) }\end{array}$ & Angel et al. (2011) \\
\hline
\end{tabular}


concern about its character, functionality, evolution, or which objectives were set for this land and if these were related to other goals (Ritchie and Spencer, 1994; Lemon, 2005). In each plan, the following aspects were identified: i) the model of development and the corresponding role of agricultural activities; ii) rural-urban relationships and urban pressure on agricultural land - land classification and regulation of uses and activities, with special attention paid to those that affect periurban agricultural land and the relationship between urban growth, infrastructure development (direction, location), and land value; iii) consideration of the selected ecosystem services, indicating, if applicable, measures planned to promote them; and iv) degree of development and possible land that could be reclassified as agricultural.

For the quantitative analysis, urban areas and infrastructures, both planned and developed, were mapped. The objective was to compare the predictions in schemes with the real changes in land cover, and to assess whether urban developments are coherent with the underlying ecosystems in areas that have been classified for urbanization.

\section{Understanding local perceptions of ecosystem services}

The project implemented a participatory action research (Alberich, 2000; Villasante et al., 2000, 2006). This type of research successfully facilitates the process of engaging with key actors. It offers the opportunity to improve the process of social learning and knowledge sharing, regarding the connection between society and ecosystems (Freire, 1993; Pretty, 2003; HernandezJimenez et al., 2009).

This analysis focuses on i) identifying actors within our system of interest, their perception of ecosystem services, and how it affects their management of the territory, ii) detecting the 'gaps' and difficulties in the adoption of the ES approach by these actors, and iii) identifying factors relating to resistance to change. Prior desk-based study work was necessary to locate and identify those actors at different institutional levels, whose management has an impact on the territory. This information was used to select the interviewees. Selection criteria were established to include i) municipal and regional technicians and politicians from different levels and competences and from different departments related to the agrarian sector, ii) farmers with different types of models of production and ideology at their exploitation, and iii) civil society organizations interested in the surrounding environment of their city.

Semi-structured interviews were split into two blocks. A first block of bi-directional presentation, in which the PAEc-SP team explained the project and its main aims, and the actors introduced themselves and their everyday activity related to the periurban territory. A second block consisted of a series of brief and strategic questions for each service, aiming to create a dialogue and to establish a trust network between the interviewer and the interviewee. Questions were based on an interview script that listed perception and management inquiries about the ES analyzed. Depending on the person interviewed, it was possible to expand on certain services. Some of these actors share a spatial planning culture, however, not all of them do. The interviewers displayed geographical visualizations of the territory, prompting each interviewee to evaluate the ecosystem services: supply (food), regulation (water, climate, soil erosion, and soil fertility), support (biodiversity), and culture (landscape and recreation). For each ES, four key issues were discussed: i) responsibilities and interaction with other stakeholders, ii) basic evaluation of current service, iii) threats, and iv) ways to promote a certain ecosystem.

Discourse analysis is central to this type of social research (Ibáñez, 1985; Wodak, 2004; Montañés, 2010); it consists of an interpretation of key literature and the main ideas introduced during the interviews. This analysis helps to define the positions and strategies of actors, map stakeholders, identify milestones in the issue at hand, and enrich and corroborate the information previously sought through other sources. The information obtained through the interviews was synthesized in a socio-gram which reflects the relationships (power, conflict, etc.) and trust networks between actors and other stakeholders connected to periurban agricultural areas. These socio-grams give a snapshot of the social interactions in the territory, which include positive and negative relationships and connections (Naredo and García Zaldívar, 2008; Briz et al., 2011; EME, 2011).

Once these steps were completed, the newly acquired knowledge was instrumental in an analysis of governance, in which the pros and cons of the inclusion of periurban agrarian sites in land planning were identified.

\section{Results}

\section{Testing the methodology through case studies}

The analysis of the 29 medium-sized cities reveals that "the urban pressure on agricultural land between 2000 and 2006 was three times higher than that on forest and semi-natural land. Ninety-nine percent of the agricultural land that was lost was transformed into artificial-urban areas" (Simon Rojo et al., 2012b). These results confirm the need to address the way in which agro-ecosystems are considered in spatial planning.

The second phase of the research focused on specific case studies to explore the opportunity of the ES approach to lay the foundation for progress into public policies and alternative governance to re-position the agricultural land benefits and constraints in spatial planning (Galli et al., 2010).

The research applied the methodology to three case studies, Valladolid, Ciudad Real, and Aranjuez. In order to 
explain clearly the outcomes of this process, one of them is described in detail here: the city of Aranjuez, in Madrid (Figure 2). The outcomes of the other two cases were taken into account when assessing the validity of the methodology and their lessons were useful to re-address it, as explained in the last section of the paper.

Aranjuez and its periurban area meet optimal conditions for analyzing the potential of agrarian ES and how they are perceived, planned, and managed. Aranjuez is located in a fertile plain at the confluence of the rivers Tajo and Jarama. By the sixteenth century, it was declared a royal site and for some centuries was emblematic as one of Madrid's food sources (CM 1999, 2002, 2009).

In 2001, UNESCO included the Aranjuez Cultural Landscape on the World Heritage List. "The Aranjuez cultural landscape is an entity of complex relationships: between nature and human activity, between sinuous watercourses and geometric landscape design, between the rural and the urban, between forest landscape and the delicately modulated architecture of its palatial buildings" (Merlos, 2012).

\section{Development and implementation of indicators for ecosystem services assessment}

The set of indicators developed was applied to produce a series of maps and graphs, which represent capacity, current balance, and trends over time in the provision of services in periurban areas. The provision of services does not only depend on land cover, but mainly on management practices (Power, 2010), for which the GIS databases available provide barely any information.

Regulating services include carbon storage and water quality. The carbon fixation rates by different land covers adapted to Mediterranean ecosystems were obtained from the OSE (OSE, 2006). In Aranjuez, the current balance of $\mathrm{CO}_{2}$ storage is negative, as more $\mathrm{CO}_{2}$ is emitted than stored, and has worsened compared to 25 years ago (Table 2).

Between 1980 and 2006, the area capacity remained approximately the same since the increase of urbanization was compensated by the change of land cover from agriculture to shrubs, brought on by the abandonment of crops. Despite this sustained capacity, the trend is negative due to both population growth $(60 \%$ more inhabitants in 2006 than in 1980) and an increase in $\mathrm{CO}_{2}$ tons emitted per capita from 5.7 in 1980 to 7.9 in 2006 (Banco Mundial, 2012). This means that in $1980,94 \%$ of the $\mathrm{CO}_{2}$ locally emitted could be stored, while in 2006, the figure has dropped to $30 \%$.

Water quality regulation is not assured due to the leaching of nitrates, caused mainly by agricultural practices because of either an excessive or an inadequate use of fertilizers in agriculture (Fernandez Ruiz, 2012). All groundwater bodies in the area are affected by nitrate pollution, and have been defined as at risk of not complying with the environmental objectives of the Water Framework Directive by 2015 (MAGRAMA, 2008). As can be seen in Figure 3, underwater bodies located in the river basin have more than $25 \mathrm{mg} / \mathrm{L}$ of nitrates, and the one located under the dryland farming ecosystem more than $50 \mathrm{mg} / \mathrm{L}$, which is the limit for nitrate pollution in water suitable for human consumption (RD 140/2003). In the period 1980-2006 the medium values of nitrates concentration have remained in the same ranges (MAGRAMA, 2009) and so the negative impact of agriculture in this service is stable.

The main provisioning service under consideration is food production, specifically fruit and vegetables in the irrigated crop land ecosystems, cereals and legumes in the dryland farming ecosystems, and olives in the olive grove ecosystems. In all cases, the capacity of the area is very high, reaching a regional scale (Figure 4). The area has the potential to feed its population twice over with non-

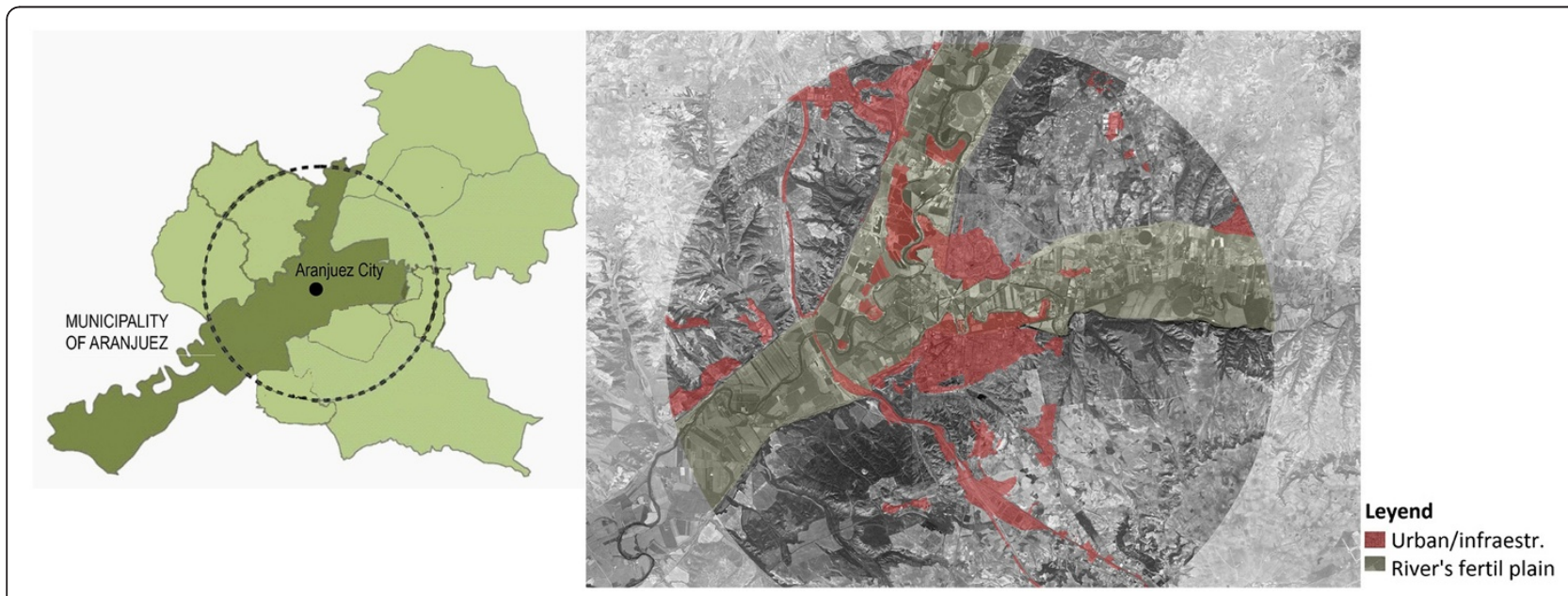

Figure 2 Case study: Aranjuez. 
Table 2 Regulating services; $\mathrm{CO}_{2}$ storage by ecosystem

\begin{tabular}{|c|c|c|c|c|c|c|c|c|c|}
\hline & \multirow{2}{*}{$\begin{array}{l}\mathrm{CO}_{2} \text { storage by ecosystem } \\
\text { Ecosystem }\end{array}$} & \multicolumn{4}{|l|}{1980} & \multicolumn{4}{|l|}{2006} \\
\hline & & $\begin{array}{l}\text { Storage capacity* } \\
\text { ton/ha }\end{array}$ & $\begin{array}{l}\text { Area** }^{* *} \\
h a\end{array}$ & \multicolumn{2}{|l|}{$\begin{array}{l}\mathrm{CO}_{2} \text { stored } \\
\text { ton }\end{array}$} & $\begin{array}{l}\text { Storage capacity* } \\
\text { ton/ha }\end{array}$ & $\begin{array}{l}\text { Area** }^{* *} \\
h a\end{array}$ & \multicolumn{2}{|l|}{$\begin{array}{l}\mathrm{CO}_{2} \text { stored } \\
\text { ton }\end{array}$} \\
\hline A & Urban-industrial & 0.00 & 2,323.22 & 0.00 & & 0.00 & $3,677.55$ & 0.00 & \\
\hline$A G$ & Water & 0.00 & 336.71 & 0.00 & & 0.00 & 214.74 & 0.00 & \\
\hline $\mathrm{CH}$ & Irrigated land & 3.20 & $6,536.84$ & $20,917.87$ & & 3.20 & $6,256.07$ & $20,019.42$ & \\
\hline L & Dryland farming & 2.20 & $8,149.19$ & $17,928.22$ & & 2.20 & $8,239.97$ & $18,127.93$ & \\
\hline M & Shrubs & 10.00 & $4,779.70$ & $47,796.99$ & & 10.00 & $3,112.54$ & $31,125.38$ & \\
\hline MA & Dense shrubs & 14.50 & 4,306.42 & $62,443.14$ & & 14.50 & $1,211.42$ & $17,565.61$ & \\
\hline $\mathrm{O}$ & Vineyard and/or olive grove & 6.10 & $3,383.75$ & $20,640.86$ & & 6.10 & $2,694.58$ & $16,436.93$ & \\
\hline$P$ & Pastures & 1.50 & $1,064.28$ & $1,596.42$ & & 1.50 & $5,473.25$ & $8,209.87$ & \\
\hline \multirow[t]{6}{*}{ VR } & Gallery forest (riparian veg) & 38.00 & 535.34 & $20,342.86$ & & 38.00 & 535.34 & $20,342.86$ & \\
\hline & & & $31,415.45$ & $191,666.37$ & & & $31,415.45$ & $131,828.00$ & \\
\hline & $\mathrm{CO}_{2}$ emission & 1980 & & & & 2006 & & & \\
\hline & & $\begin{array}{l}\text { Emission per } \\
\text { capita }^{* * * *}\end{array}$ & Population ${ }^{* * * *}$ & $\begin{array}{l}\mathrm{CO}_{2} \\
\text { emitted }\end{array}$ & Balance & $\begin{array}{l}\text { Emission per } \\
\text { capita }^{* * *}\end{array}$ & Population $^{* * * *}$ & $\begin{array}{l}\mathrm{CO}_{2} \\
\text { emitted }\end{array}$ & Balance \\
\hline & & ton/inhab & inhab & ton & $\%$ & ton/inhab & inhab & ton & $\%$ \\
\hline & & 5.70 & $35,619.00$ & $203,028.30$ & 94.40 & 7.90 & $56,877.00$ & $449,328.30$ & 29.34 \\
\hline
\end{tabular}

*OSE (2006).

**PAEc-SP ecosystems.

***Banco Mundial (2012).

****INE (2007) Instituto Nacional de Estadistica.

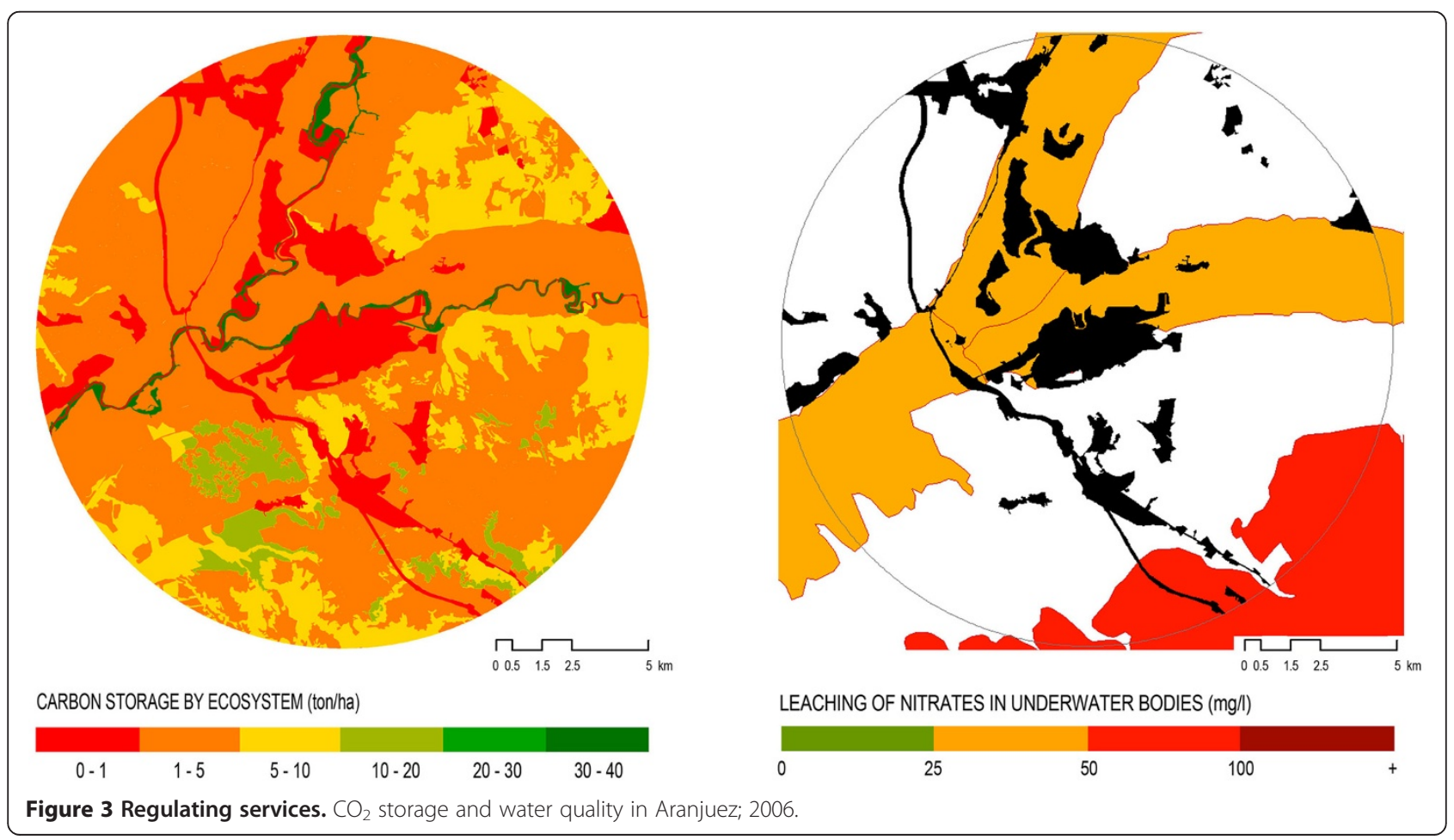




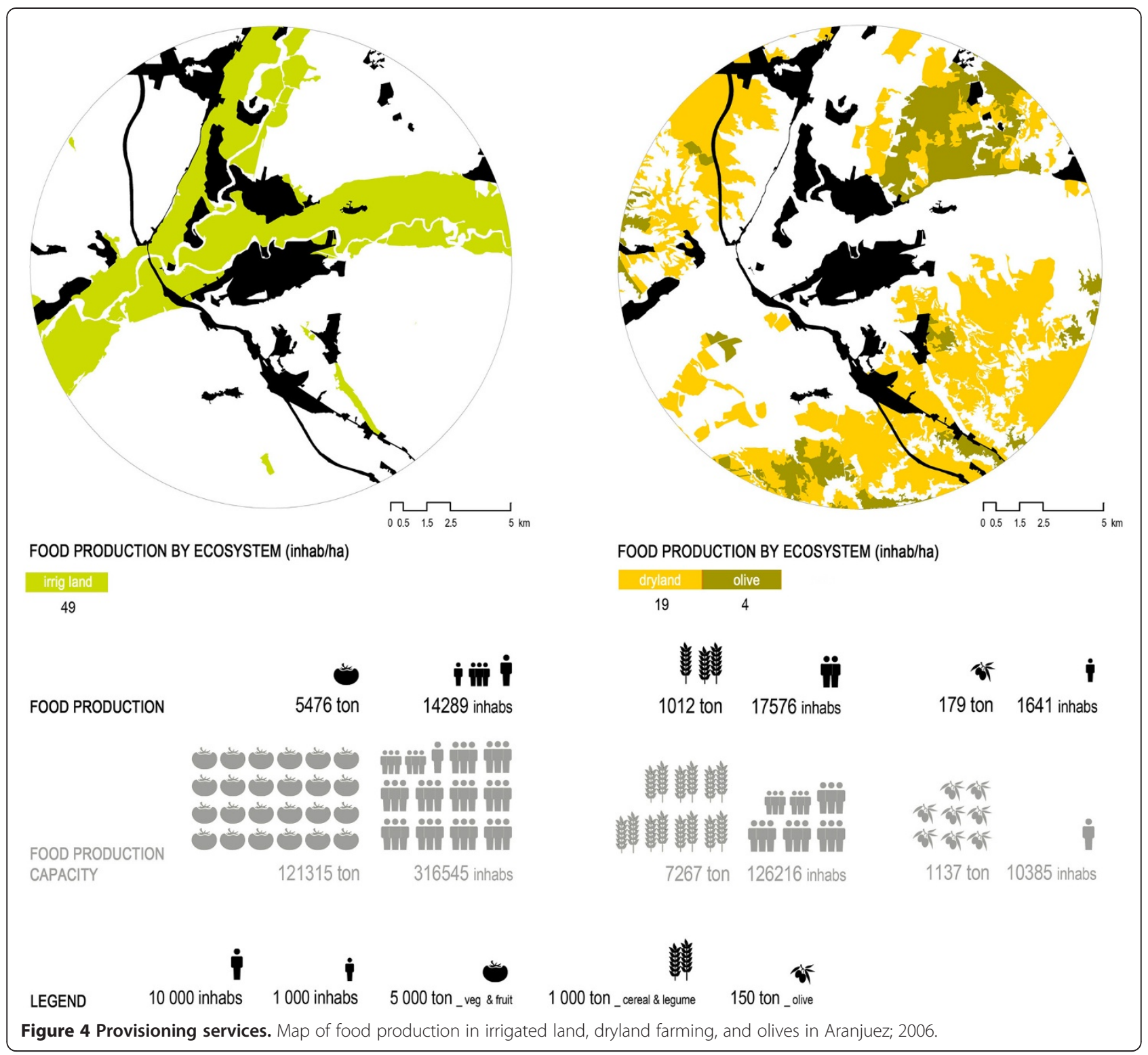

irrigated crops and five times over with irrigated crops. While there is no specific information on food production at the local scale, these figures are estimations based on aggregated data at a regional scale. Food production capacity has been calculated from the current agricultural yields in the area, published in the Statistical Yearbook (MAGRAMA, 2007), and applied to the surface of available productive land, supposing that the whole area was used for growing food (instead of forages or other crops). The state of food production has been estimated from the Madrid region production data published by the same source, maintaining the regional distribution of crops. Based on these calculations (Table 3), the provision of services cannot be assessed as positive, as current agricultural production is far from its full capacity and is even unable to provide for the needs of the local population.
The trend is negative because of the loss of agricultural land, due to agricultural land urbanization or abandonment, and the changes in crops from traditional vegetables to extensive crops; a process that began prior to the 1980s (Mata and Rodríguez, 1987).

Cultural services provided by periurban areas in Aranjuez are also high, including both cultural identity and recreation services. The heritage and recreation opportunity spectrum indicators, adapted from Maes et al. (2011), are mapped through a gradient that shows the density of elements by $\mathrm{km}^{2}$, and their proximity to the city center. Figure 5 shows these recreational areas.

The area is home to a rich heritage, linked to historical agricultural uses and cultural landscape (channels, wineries, farms, orchards, and tree-lined avenues, etc.), elements which are protected by municipal urban planning as well as 
Table 3 Provisioning services

\begin{tabular}{|c|c|c|c|c|c|c|}
\hline \multicolumn{7}{|c|}{ Food production capacity, state and balance in Aranjuez (2006) } \\
\hline \multirow[t]{2}{*}{ Ecosystem } & Available area & Crop yield & Production capacity & Food needed & $\begin{array}{l}\text { Capacity to } \\
\text { feed people }\end{array}$ & $\begin{array}{l}\text { Capacity to feed } \\
\text { people by ha }\end{array}$ \\
\hline & ha & $\mathrm{kg} / \mathrm{ha}$ & $\mathrm{kg}$ & $\mathrm{kg} / \mathrm{hab}$ & inhab & inhab/ha \\
\hline Irrigated land & $6,458.26$ & & $121,315,783.50$ & 383.25 & 316,545 & 49 \\
\hline Vegetables 57\% & $3,681.21$ & $18,810.67$ & $69,246,027.11$ & 219.00 & 316,192 & 86 \\
\hline Fruit 43\% & $2,777.05$ & $18,750.00$ & $52,069,756.39$ & 164.25 & 317,015 & 114 \\
\hline Dry land farming & $6,509.67$ & & $7,267,530.68$ & 57.58 & 126,216 & 19 \\
\hline Cereal 36.5\% & $2,376.03$ & $2,138.00$ & $5,079,954.60$ & 40.11 & 126.651 & 53 \\
\hline Legume 43\% & $2,799.16$ & 495.00 & $1,385,584.19$ & 10.95 & 126,537 & 45 \\
\hline Nuts $20 \%$ & $1,301.93$ & 616.00 & $801,991.88$ & 6.52 & 123.005 & 94 \\
\hline Olive & $2,694.58$ & 422.00 & $1,137,112.25$ & 109.50 & 10,385 & 3.85 \\
\hline \multicolumn{7}{|c|}{ Food produced capacity, state and balance in Aranjuez (2006) } \\
\hline \multirow[t]{2}{*}{ Ecosystem } & $\begin{array}{l}\text { Area relative to } \\
\text { Madrid region }\end{array}$ & & $\begin{array}{l}\text { Food produced } \\
\text { (estimated from } \\
\text { regional production) }\end{array}$ & Food needed & People fed & \\
\hline & $\%$ & & $\mathrm{~kg}$ & $\mathrm{~kg} / \mathrm{inhab}$ & inhab & \\
\hline Irrigated land & 19.89 & & $5,476,200$ & 383.25 & 14,289 & \\
\hline Vegetables & & & $3,180,200$ & 219.00 & 14,521 & \\
\hline Fruit & & & $2,296,000$ & 164.25 & 13,979 & \\
\hline Dry land farming & 5.91 & & $1,012,027$ & 57.58 & 17,576 & \\
\hline Cereal & & & 975,270 & 40.11 & 24,315 & \\
\hline Legume & & & 19,647 & 10.95 & 1,794 & \\
\hline Nuts & & & 17,110 & 6.52 & 2,624 & \\
\hline Olive & 11.3 & & 179,640 & 109.50 & 1,641 & \\
\hline
\end{tabular}

national and international legislation. The density of cultural elements is higher in areas close to the city, so the opportunities to access it are very good for short routes (up to 1.5 hours, grades 1-4), and good for longer routes (up to 5 hours, grades 5-8) as can be seen in Figure 5. The trend has been positive, new protection boundaries have been defined, and the periurban space has received global recognition by UNESCO.

Recreational facilities are sufficiently diverse (outdoor leisure areas, picnic, boating, swimming, recreational fishing, cycling, horse riding, walking, etc.). They are mainly located near the urban center and thus there is little opportunity for long routes.

Supporting services include biodiversity, which is analyzed through ecological connectivity, mapping the fragmentation caused by urban uses and the continuity of open spaces.

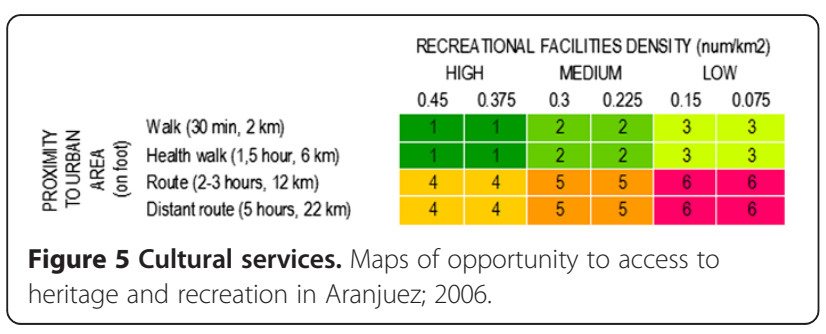

Ecological connectivity is not assured, as can be observed in the map (Figure 6). The impact of urban sprawl is higher in the river basin, an irrigated land ecosystem important for provisioning and cultural services. The density of open areas is high but is located in the east and southwest of the city; the motorway impact is isolating some areas. The trend since the 1980s is negative because of the increase in infrastructure and discontinuous urban fabric.

\section{Recognition of ecosystem services in spatial plans}

The spatial plans analyzed were drawn in the framework of conventional instrumental rationality (Voogd and Wotjer, 1999) with quite a technocratic approach. In any case, they are a reflection of public policies, which in turn represent the aspirations of the society. Their analysis serves to illustrate the importance of agricultural areas and their functions or services for society.

At municipal level, six master plans were analyzed: Municipality of Aranjuez (1996) Plan General de Ordenación Urbana, Municipality of Borox (1985) Normas Subsidiarias de Planeamiento, Municipality of Colmenar (1985) Normas Subsidiarias de Planeamiento, Municipality of Ocaña (1981) Normas Subsidiarias de Planeamiento, Municipality of 


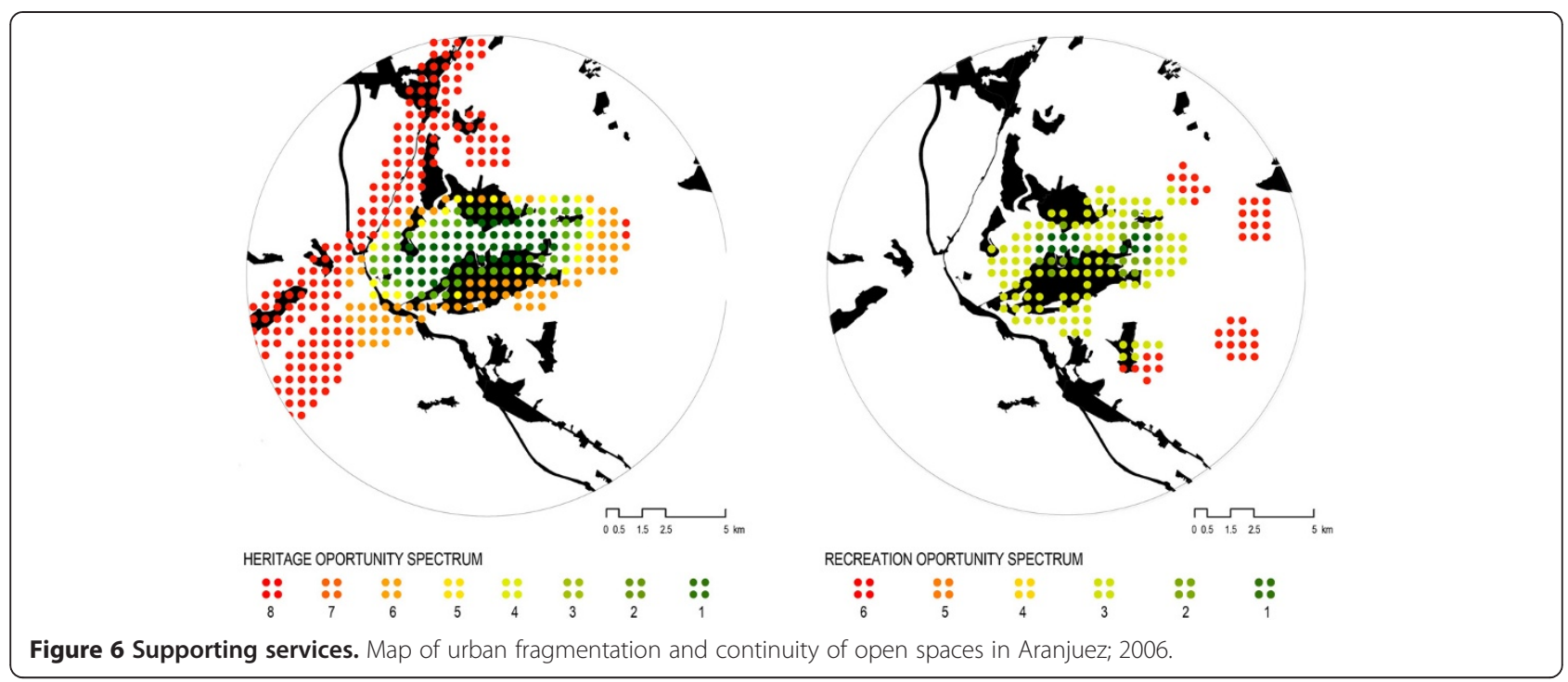

Ontigola (1995) Normas Subsidiarias de Planeamiento, and Municipality of Seseña (1996) Normas Subsidiarias de Planeamiento. They are binding documents, passed by the City Council and the Regional Government (Autonomous Community) between 1981 and 1999.

Given the agricultural history of the area, it is not surprising that provisioning services, in particular food production, are considered a top issue in almost every document analyzed. Five plans set the goal of preserving agricultural areas and stopping future urban development from having adverse effects on them. The second most common services integrated in these spatial plans are cultural services, provided by agrarian ecosystems. Four out of six plans aim to protect and promote specific agrarian land due to its cultural value and, in some cases, the plan is also aimed at preserving the 'agrarian character' of the village (Municipality of Borox), or the strong tradition of agrarian activities (Municipality of Colmenar).

Four plans emphasize the importance of enhancing biodiversity, however, they do not associate this goal with agrarian land, but rather with 'natural land' or specially protected areas.

At regional level one plan for rural development (Territorial Program for the Comarca de Ocana, 2011) and three plans for environmentally protected areas and parks (PORN 02 Mar de Ontigola, and PORN 99 \& PRUG 09 Manzanares and Jarama rivers) were analyzed. The main goal of each plan is to protect and improve natural resources. Each plan divides the regional park into zones with different degrees of protection. The areas at the periurban fringe of Aranjuez are considered for the exploitation of natural resources.

The environmental management plans do refer to the provisioning services of agrarian ecosystems and encourage the uptake of organic farming, as they stress the impact the sector has on water quality. However, the plan does not consider the role these areas may fulfill in enhancing biodiversity.

Under the stagnant approach, no proactive measure is established to this end. Only in the buffer zones, close to those zones with the highest natural value, are mining activities forbidden. There are general considerations about preserving historical patrimony, but the document does not stipulate anything when regulating uses and activities in agrarian land.

\section{Actors' perceptions}

The first stage involved desk-work. It consisted in identifying those actors with diverse competences and interests described in the methods section. This work culminated in a preliminary socio-gram.

The second stage involved fieldwork in Aranjuez. Twelve individual, semi-structured interviews and one group interview were conducted in 2013. Relevant territorial planners and managers were selected for the interviews: politicians and municipal technicians, farmers, water management organizations, and agricultural trade unions. The results provided several types of information, such as i) helping the PAEC team to understand relationships and hidden networks among actors (institutions, administrations and individuals), ii) information about actors' perception on ES, and iii) providing the PAEC team with information about actors' management of the territory.

The relationships detected are, mostly, vertical and hierarchical, as shown in Figure 7. Departments from the same institutional level have neither cooperation nor connection between them. These phenomena are common at institutional level, but they are repeated at the local level too, where this is especially important because neither 
civil society nor farmers seem to be prepared to work together to build a common vision for their city.

The results of this stage are some participatory maps and a key diagram (Figure 8) that relates the actors' perception of ES (right columns) with ES that are taken into account in their day-to-day management of the territory (left columns).

Regarding the perception that actors have about ES, firstly, it is necessary to emphasize the dominant role all actors give to provisioning services in Aranjuez. This is due to the agrarian and historical heritage of this territory. The progressive construction of an irrigation network of ditches from the sixteenth century highlights that agriculture was the main driver of the region until the last decades of the twentieth century. Nearly all actors understand their work is related to the provisioning of food, although the destination of the production (local, regional, or global market) has very little relevance to their perception, in most cases. Technicians from the environmental and cultural departments consider this service is not part of their competence. However, an even more worrying result is that local development technicians do consider it, but have no competence in it. Secondly, it is necessary to highlight the importance of cultural services for most of the actors. Aranjuez has the peculiarity of being a World Cultural Landscape' listed by UNESCO, and its landscape cultural heritage has traditionally been one of the major attractions for tourism. However, in general, just the defined area is well considered while the rest of the periurban ecosystems are not taken into account. In relation to supporting services, more than half of the actors refer to biodiversity as one of the characteristics of their territory. Finally, regulating services do not appear to be relevant for the actors interviewed. Just a few actors consider the interaction between agriculture and water and soil regulation, and even fewer consider its role for climate regulation or $\mathrm{CO}_{2}$ storage. When regulating services are concerned, the absence of regulating services in the collective imagination is particularly relevant.

Regarding the consideration of ES by the different actors in their management of the territory, in most cases, the territorial actors are aware of far fewer ES than those affected by their day-to-day activities. It is significant that, even though technicians at a local and regional institutional level have a greater responsibility for territorial issues, they tended to be specific and sectoral.

\section{Discussion}

The final step involves comparing the partial results to substantiate the potentialities and limitations of integrating the ES approach in spatial planning processes. One important lesson to be drawn from the research is that actors do not internalize equally all ES from agricultural areas, plans do not take them into account in the same way, and their state and evolution is also different, as summarized in Figure 9.

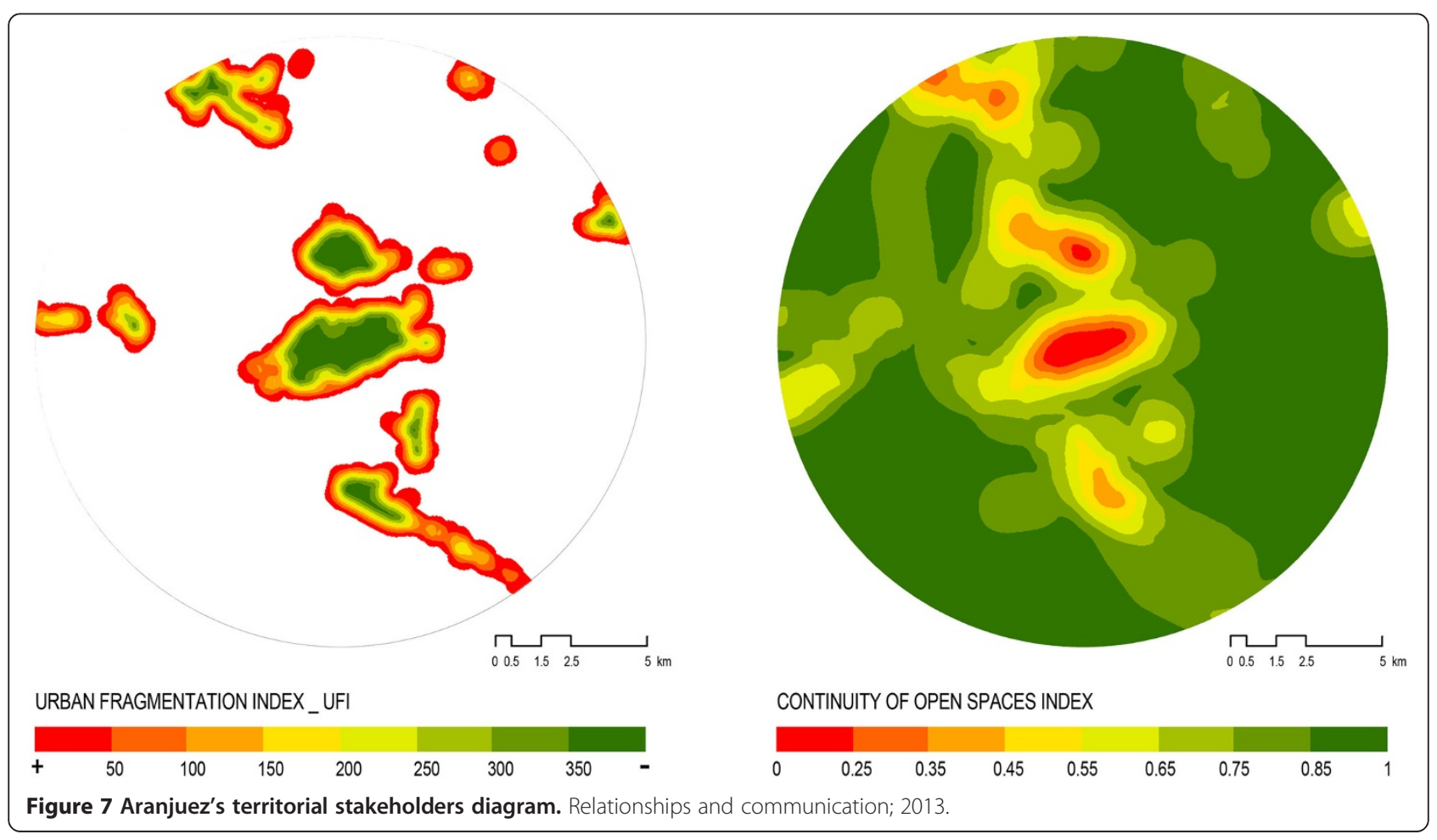




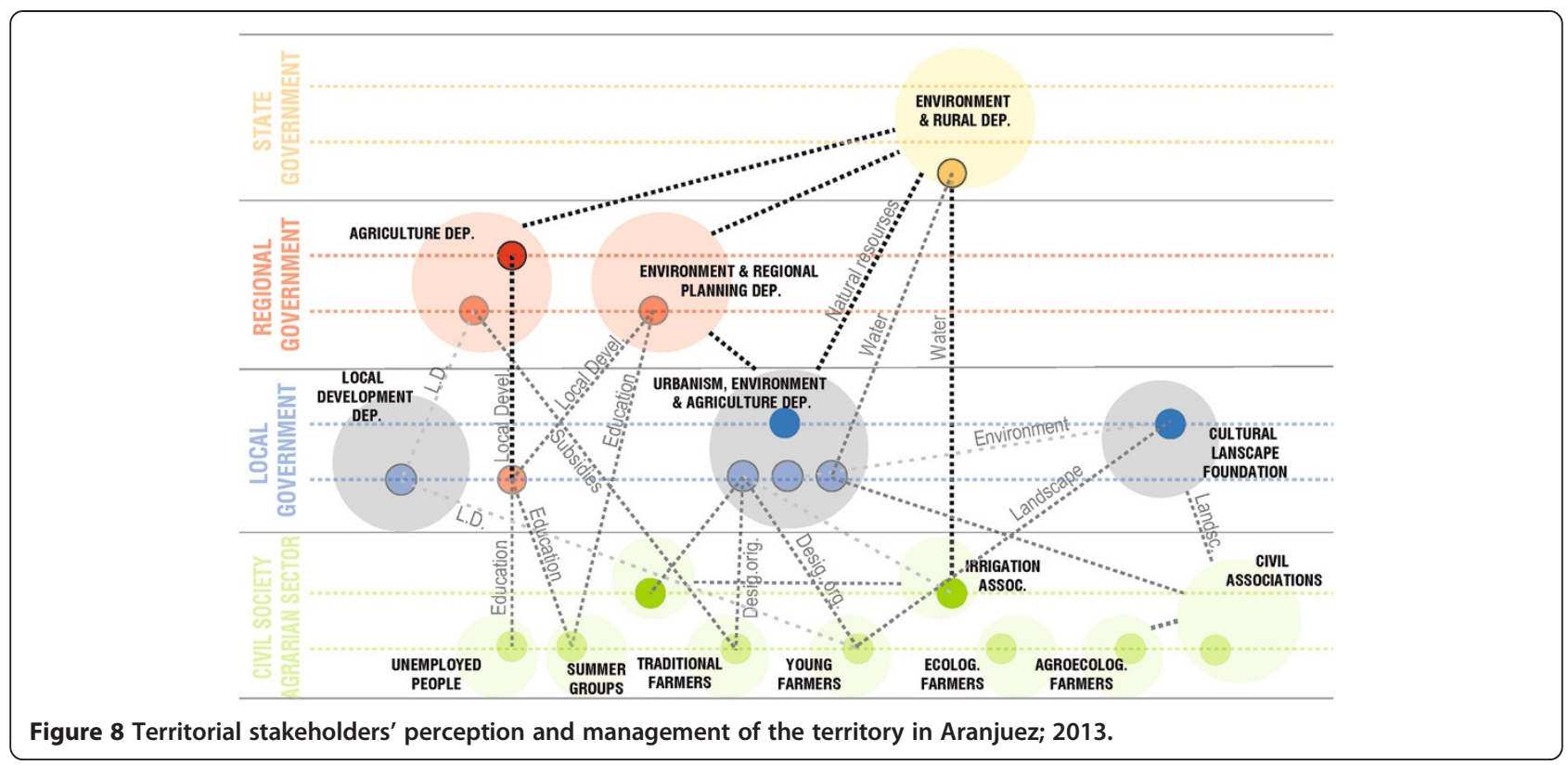

\section{Regulating services}

Although the role of agrarian ecosystems in the provision of services such as $\mathrm{CO}_{2}$ storage is clearly shown by indicators, spatial planning barely addresses them and stakeholders do not value them either. Given current climate policy mainstreaming and the widespread recognition of the urgency of the climate change challenge, it should be easily integrated in future planning processes. Water quality is a degraded service but not perceived as significant at local level, either in urban planning or by stakeholders. The competent body to address this issue is the River Basin Authority, but the city authorities and farmer's responsibilities are essential.

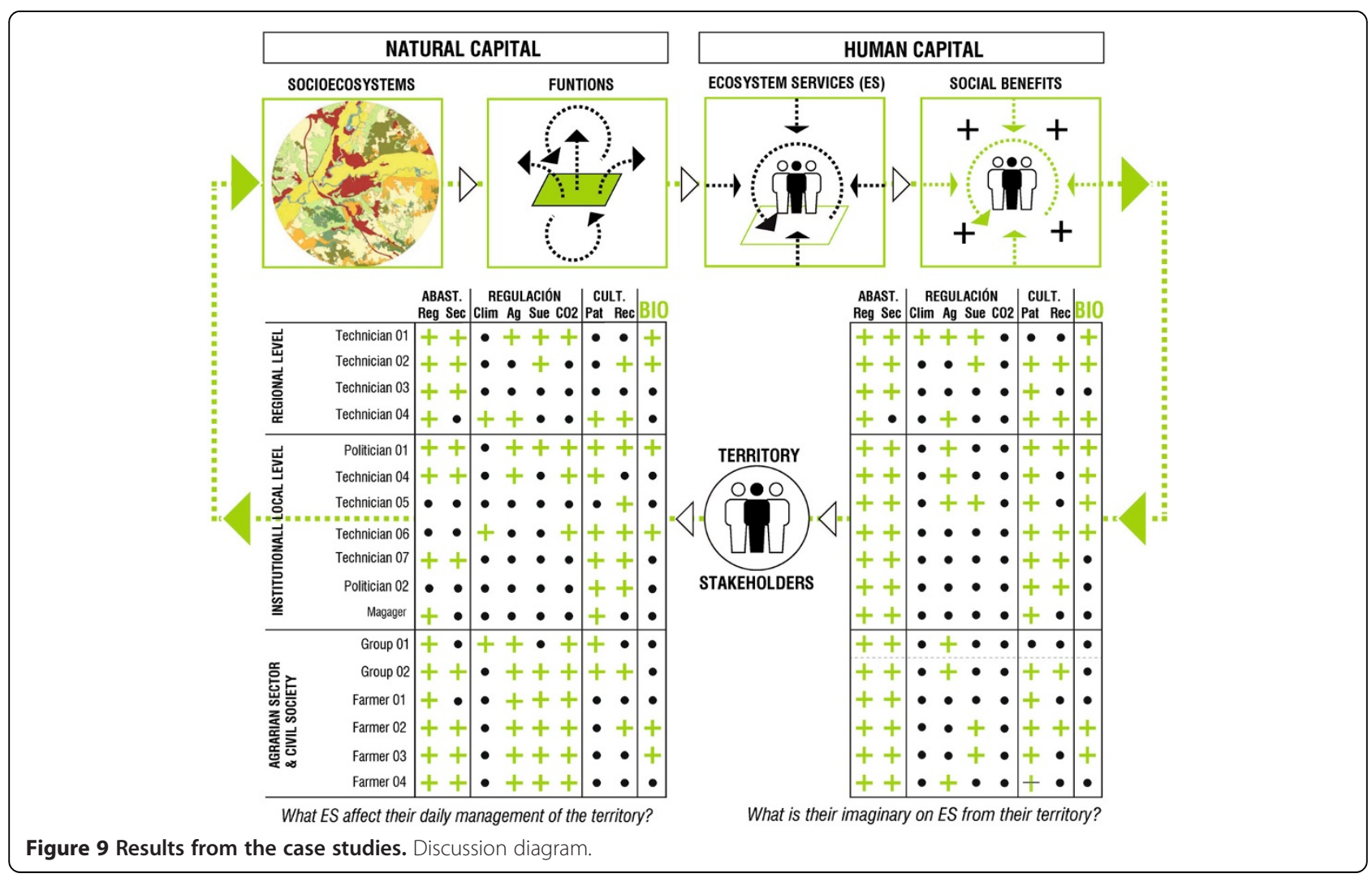




\section{Provisioning services}

Due to the traditional agrarian character of the area, this service is widely perceived by stakeholders, and is valued and recognized in spatial planning. Nevertheless, the current food production is substantially below the area's capacity. Agrarian production is not linked to the local food system, so there are neither regulatory requirements, nor farmer's actions in this regard.

\section{Cultural services}

There is also a big potentiality, especially in cultural identity, because of the area's heritage. This is recognized by all stakeholders and addressed by local urban planning. Nevertheless, heritage is not understood as interconnected to farming practices, but more as cultural heritage that must be protected. Riding facilities raise discussion between different actors. Recreation associated to farming is not so widely valued, practically only the rural development program suggests it can be a valuable asset.

\section{Supporting services}

Environmental issues are still not sufficiently integrated in farming practices or in spatial planning of agrarian spaces. There are actors that, even if they recognize the importance of agricultural ecosystems for biodiversity, they maintain a conventional management approach in which semi-natural protected areas and agricultural ones belong to different isolated realms; the same can be said of most spatial plans. The measures that those plans include to enhance biodiversity are just applied to protected areas, regardless of the role that agrarian ecosystems could play. Maybe the connection of local agrarian ecosystems to biodiversity is difficult to understand but local actions are essential to their provision.

These differences have clear implications for the strategy of implementing the ES approach. Provisioning services which, if connected to healthy food and short-supply chains have gained an additional social legitimacy, can act as leverage to introduce the concepts of ES. In some cases like Valladolid, and particularly Aranjuez, cultural services linked to identity can also be a powerful element. On the contrary, the water quality service should be avoided, not only because of its little recognition, but also because of the minor competence in spatial planning for this problem. In any case, if one specific service is weighed too heavily it can mislead a comprehensive understanding of ES and trade-offs between them. For example, if the $\mathrm{CO}_{2}$ storage is considered paramount, the decision can be strongly based towards replacing agriculture by forestry.

It should not be disregarded that services generated at a local scale can provide regional or even global benefits, which is especially relevant in the PAEc-SP case studies. As an example, both Aranjuez and Ciudad Real could produce more food than the amount required to feed local populations; a regional analysis would envisage territorial, rather than local, needs and the role of all areas in the regional system. In fact, the implementation of the ES approach is hindered by a mismatch between administrative boundaries and ecological areas. Ecosystem boundaries do not correspond with the boundaries drawn up by administrative plans. Moreover, the function that each agrarian space can carry out should not be contingent on the different criteria of each planning team. This contingency could be avoided with the cooperation of regional authorities. For example, the environmental agency (regional level) could specify the spatial requirements for the habitats of different species (e.g., the type of connectivity) and the implications for agrarian areas in-between.

Mapping ES in periurban areas has proved useful to provide decision makers and planners with spatialized information about strategic areas that should be protected or changed, in order to improve the provision of services. Maps and graphs are a valuable communication tool to discuss with different actors the consequences of the loss of agrarian ecosystems under different planning scenarios.

Nevertheless, indicators and maps are too abstract for most actors. Some services require not only quantitative indicators but qualitative information, especially in the case of cultural services. Interviews with local actors could provide the missing information.

In general terms, most of the technicians (at a local and regional level) are not in favor of changes, as they already have established responsibilities and work protocols. They seem much more willing to adapt the ES approach to their current vision, than their vision to an ES approach. Conventional farmers and groups also show a negative reaction to future changes as they would prefer to carry on with their sectoral perception and management, and not have to deal with other new dimensions. The case with young people, new farmers, and civil society involved in this process is different. They express the opinion that a new and collective approach to understanding the territory and its ecosystems more holistically is necessary.

This reluctant attitude as well as the generally incomplete and inadequate understanding of ES, render it imperative to adopt a comprehensive approach to ES through a participatory process of urban planning. It is crucial to integrate them from the very beginning of the process and to overcome barriers associated to technical language or to inadequate communication tools that divert participants from engaging in the process, e.g., providing participants with visual ad-hoc post-its and symbols (pictograms) to show services, instead of asking them to draw directly on the map. Part of the work should be performed in the region, for example, with explicative and interactive panels associated to Apps for collaborative cartography. All these tools will facilitate the discussion about desirable future scenarios. 


\section{Conclusions: How to find the pathways to build a common vision about periurban agrarian land}

The research has shown that the greatest obstacles to building a common vision to integrate periurban agrarian land into the spatial planning system were connected to i) the retention of a spatial planning system that establishes narrow aims for the agrarian land, ii) the institutional inertia, quite reluctant to adopt innovative processes, and iii) the attitude of most actors, who do not have a comprehensive vision and understanding of the ecological and territorial inter-dependencies.

Spatial planning has traditionally disregarded many functions of the territory. Urban planning has been oriented mainly towards urban development and, as a result, the agrarian land is not considered to be valuable by itself. Its contribution to urban quality of life is not clearly perceived; therefore, it is weakly protected and not regulated in detail. Some new objectives for farming, such as local food or multifunctionality, should be included in urban planning, although this innovation could have opposition from several actors. Since institutional structures are quite rigid and do not adapt rapidly to changes, several phases are needed to achieve these changes gradually. Moreover, institutions usually have a short-term vision conditioned by the political cycles of elections every four years.

Competencies are divided sectorally and territorially, which results in inconsistencies, overlaps, and gaps in their plans. Decisions taken in one area have consequences for others, so a higher level of collaboration, transversality, and common objectives are needed in order to develop collaborative actions. Most of the relevant actors who plan and manage the territory do not have a complete picture or understanding of the socio-ecological systems functioning and their interdependency. They are usually quite reluctant to adopt recommendations or obligations established by spatial plans, which are seen as impositions from external experts ignorant of real local conditions.

At this point, building a common vision of the urban and territorial system is absolutely necessary, engaging not only authorities and technician, but also other actors such as farmers, urban economic actors, social movements, and citizens. Their involvement is essential for successfully shifting from individual and economic objectives to 'common good' approaches. These actors should be engaged from the very beginning of the process, instead of presenting them with the plans at a later date.

The results emphasize the need for understanding the impact of different scenarios, public policies, and design options. In most cases, this can only be done by adopting a clear and simple methodological framework, which clarifies the concepts of ES and how to use them throughout the process. It is difficult to work together on the territorial interactions of the different ecosystems and their implication for well-being. To facilitate the process, concepts are presented in a common language through the spatial representation of indicators and visualization tools which include local icons and specific pictograms. The PAEc-Sp has developed a methodology for mapping services through indicators. With these maps it is possible to understand interactions and to visualize the influence that each proposal has in the provision of services and the quality of ecosystems. The amount of services considered is small to keep it simple and operational. The goal is to arouse interest in the key role that periurban agriculture and farmers play in the well-being of society, laying the foundations of new urban-rural relationships, and once these benefits are widely acknowledged new ones will follow.

\section{Endnotes}

${ }^{\text {a }}$ The first attempt to geographically define periurban areas was done by the Organization for Cooperation and Economic Development (ECDE) in 1979, which (from a regional and population approach) defined periurban as an area with a radius of $20 \mathrm{~km}$ around cities with a population of more than 200,000 inhabitants; a radius of $15 \mathrm{~km}$ around cities with a population of 100,000 to 200,000; and a radius of $10 \mathrm{~km}$ around cities with a population of 50,000 to 100,000 (OCDE, 1979).

${ }^{b}$ PAEc-Sp is a R\&D project funded by the MICINN (Spanish Ministry of Science and Innovation). The project spans from January 2012 to December 2014.

${ }^{\mathrm{c}}$ Millennium Ecosystem Assessment in Spain (EME, 2011), TEEB - The Economics of Ecosystems and Biodiversity (2010), Action 5 EU Biodiversity Strategy to 2020 (Maes et al., 2013), Millennium Ecosystem Assessment (2003), United Kingdom Assessment (NEA, 2011), Millennium Ecosystem Assessment in Switzerland (Staub et al., 2011).

\section{Abbreviations \\ CM: Comunidad de Madrid (year); EEA: European Environment Agency; ES: Ecosystem services; PAEc-Sp: Integrating Periurban Agrarian Ecosystems in Spatial planning}

\section{Competing interests}

The authors declare that they have no competing interests.

\section{Authors' contributions}

All authors read and approved the final manuscript.

\section{Author details}

${ }^{1}$ GIAUS (Architecture, Urbanism and Sustainability Research Group), School of Architecture, Technical University of Madrid, Avda. Juan de Herrera s/n., 28040 Madrid, Spain. 'ECOPAI (Ecology and Landscape Research Group), School of Forestry, Polytechnical University of Madrid, Avda. Ramiro de Maeztu s/n., 28040 Madrid, Spain

Received: 1 October 2013 Accepted: 15 May 2014

Published online: 27 August 2014

\section{References}

Alberich T (2000) Perspectivas de la investigación social. In: Rodríguez Villasante T, Montañéz M, Martí J (eds) La investigación social participativa. El viejo topo, Madrid 
Angel S, Parent J, Civco DL, Blei AM (2011) Making room for a planet of cities. Policy Focus Report, Lincoln Institute of Land Policy, Cambridge, MA

Antrop M (2000) Background concepts for integrated landscape analysis. Agric Ecosyst Environ 77:17-28

Aranjuez Local Government (2013) Informe Municipal Paisaje Cultural. Aranjuez, Madrid

Ay J-S, Napoleone C (2013) Efficiency and equity in land conservation: the effects of policy scale. J Environ Manag 129(15):190-198

Bell S (1999) Landscape: pattern perception and process. E \& F N Spon, London

Banco Mundial (2012) CO2 Emmission Data. Indicators databank. [http://datos. bancomundial.org/indicador/EN.ATM.CO2E.PC]. Accessed 01 Sep 2013

Briz J, Felipe I, Asunción I (2011) Cadena de valor corta: caso hortofrutícola Aranjuez-Madrid. In: Briz J, Felipe I (eds) La Cadena de Valor Agroalimentaria. Editorial Agrícola, Madrid

Bryant CR (1995) The role of local actors in transforming the urban fringe. J Rural Stud 11(3):255-267

Carbone A, Subioli G (2008) The generational turnover in agriculture: the ageing dynamics and the EU support policies to young farmers. 109th EAAE Seminar, Viterbo, Italy

CM - Comunidad de Madrid (1999) Plan de ordenación de recursos naturales del parque regional en torno a los ejes de los cursos bajos de los ríos Manzanares y Jarama. Comunidad de Madrid, Madrid

CM - Comunidad de Madrid (2002). Plan de Ordenación de Recursos Naturales de la Reserva Natural El Regajal-Mar de Ontigola

CM - Comunidad de Madrid (2009) Plan de Regulación de Usos y Gestión del Parque regional en torno a los ejes de los cursos bajos de los ríos Manzanares y Jarama, Comunidad de Madrid, Madrid

Costanza R (2008) Ecosystem services: multiple classification systems are needed. Biol Conserv 120(4):549-565

Crossman DN, Burkhard B, Nedkov S, Willemen L, Petz K, Palomo I, Drakou EG, Martı'n-Lopez B, McPhearson T, Boyanova K, Alkemade R, Egoh B, Dunbar MB, Maes J (2013) A blue print for mapping and modelling ecosystem services. Ecosystem Services 4:4-14

Darly S, Torre A (2013) Conflicts over farmland uses and the dynamics of "agri-urban" localities in the Greater Paris Region: An empirical analysis based on daily regional press and field interviews. Land Use Policy 33:90-99

de Groot R (2006) Function-analysis and valuation as a tool to assess land use conflicts in planning for sustainable, multi-functional landscapes. Landsc Urban Plan 75(3-4):175-186

EME (2011) Evaluación de Ecosistemas del Milenio en España. Conservación de los Servicios de los Ecosistemas y la biodiversidad para el bienestar humano. Informe final, UAM, Madrid

European Commission (2010) EC DG-ARD. Situation and prospects for EU Agriculture and rural areas, EC previous European Commission

Fernández Ruiz L (ed) (2012) Las aguas subterráneas en la planificación hidrogeológica. Geológico y Minero de España, Instituto

Freire P (1993) Interrogantes y propuestas. Temas de psicología social IV:13. IV, Buenos Aires

Galli M, Lardon S, Marraccini E, Bonari (eds) (2010) Agricultural management in periurban areas. The experience of an international workshop. Felici Editore, Italia

Hernandez-Jimenez V, Ocón B, Encinas MA, Pereira D, Winder NP (2009) Planificación participativa en el entorno de las grandes ciudades. In: Farinós J, Romero J, Salom J (eds) Cohesión e Inteligencia Territorial. Universitat de Valencia, Valencia

Herrera Calvo PM (2013) Una aproximación a la conectividad ecológica aplicada a la planificación territorial: modelización para el caso de Valladolid y Entorno/An approach to ecological connectivity applied tool and planning: modelling the case of Valladolid and its environs. Ciudades Dosser 1:149-240

Hewitt R, Hernandez-Jimenez V (2010) Devolved regions, fragmented landscapes: the struggle for sustainability in Madrid. Sustainability 2:1252-1281

Houston P (2005) Re-valuing the fringe: some findings on the value of agricultural production in Australia's peri-urban regions. Geogr Res 43(2):209-223

Ibáñez J (1985) Análisis sociológico de textos y discursos. Revista Internacional de Sociología 43:121-159

INE (2007) Agricltural and Population \& Housing Census. National Statistics Institute, Madrid

Lemon M (2005) Exploring environmental change using an interpretative method. Taylor and Francis E Library, The Netherlands

Lodder E (2012) Pressure on land in periurban Vietnam. The impact of agricultural land conversion and the need for livelihood diversification in Thuy Duong commune, Universiteit Utrecht, [http://igitur-archive.library.uu.nl/ student-theses/2012-1128-200503/UUindex.html] Accessed 20 August 2013
Maes J, Braat L, Jax K, Hutchins M, Furman E, Termansen M, Luque S, Paracchini ML, Chauvin C, Williams R, Volk M, Lautenbach S, Kopperoinen L, Schelhaas MJ, Weinert J, Goossen M, Dumont E, Strauch M, Görg C, Dormann C, Katwinkel M, Zulian G, Varjopuro R, Ratamäki O, Hauck J, Forsius M, Hengeveld G, Perez-Soba M, Bouraoui F, Scholz M et al (2011) A spatial assessment of ecosystem services in Europe: methods, case studies and policy analysis - phase 1. In: PEER Report No 3. Partnership for European Environmental Research, Ispra

Maes J, Teller A, Erhard M, Liquete C, Braat L, Berry P, Egoh B, Puydarrieux P, Fiorina C, Santos F, Paracchini ML, Keune H, Wittmer H, Hauck J, Fiala I, Verburg PH, Condé S, Schägner JP, San Miguel J, Estreguil C, Ostermann O, Barredo Jl, Pereira HM, Stott A, Laporte V, Meiner A, Olah B, Royo Gelabert E, Spyropoulou R, Petersen JE et al (2013) Mapping and Assessment of Ecosystems and their Services. An analytical framework for ecosystem assessments under action 5 of the EU biodiversity strategy to 2020, Publications office of the European Union, Luxembourg

MAGRAMA (2007) Ministerio de Agricultura. Anuario de estadística 2006. Superficies y producciones de cultivos, Alimentación y Medio Ambiente, España, [http://www.magrama.gob.es/es/estadistica/temas/publicaciones/ anuario-de-estadistica/2006/default.aspx] Accessed 15 Jan 2013

MAGRAMA (2008) Ministerio de Agricultura, Alimentacion y Medio ambiente. Sistema Integrado de Información del Agua, SIA, [http://servicios2.marm.es/ sia/visualizacion/descargas/documentos.jsp] Accessed 10 Sep 2012

MAGRAMA (2009) Ministerio de Agricultura. In: Apoyo a la caracterización adicional de las masas de agua subterránea en riesgo de no cumplir los objetivos medioambientales en 2015. Demarcación hidrográfica del Tajo, Alimentacion y Medio ambiente

MAGRAMA (2010) Environmental Profile of Spain. Ministry of Agriculture, Food and Environment, Madrid

Martín-López B, Gómez-Baggethun E, Montes C (2009) Un marco conceptual para la gestión de las interacciones naturaleza-sociedad en un mundo cambiante [A conceptual framework to manage interactions between nature and society in a changing world]. Cuides 3:229-258

Martín-López B, Montes C (2011) Los sistemas socioecológicos: entendiendo las relaciones entre la biodiversidad y el bienestar humano. Biodiversidad y servicios de los ecosistemas. Biodiversidad en España: base de la sostenibilidad ante el cambio global. Observatorio de la Sostenibilidad en España (OSE) 6(1):444-465

Mata R, Rodríguez I (1987) Propiedad y explotación agrarias en el regadío de las "vegas" de Madrid. Agric Soc 42:149-180

Matarán Ruiz A (2013) Participación social en la protección activa de los espacios agrarios periurbanos: un estado de la cuestión. Boletín de la Asociación de Geógrafos Españoles, pp 63-201, N.o

McGregor D, Simon D, Thompson D (eds) (2006) The peri-urban interface: Approaches to sustainable natural and human resource use. Earthscan, London

Merlos M (2012) Jornadas sobre Patrimonio como recurso Didáctico. DG. Educación y Cultura, Ayuntamiento de Aranjuez

Millenium Ecosystem Assessment (2003) Ecosystems and human well-being: a framework for assessment. Island Press, Washington

Montañés M (2010) Interpretación de textos y discursos al servicio del DesarrolloLocal. Cuadernos CIMAS, Observatorio Internacional de Ciudadania y Medio Ambiente Sostenible, Madrid

Moreno Flores O (2007) Agricultura Urbana. In: Nuevas Estrategias de Integración Social y Recuperación Ambiental en la Ciudad. Revista Electrónica DU\&P, Diseño Urbano y Paisaje Volumen IV Nº11. Centro de Estudios Arquitectónicos, Urbanísticos y del Paisaje Universidad Central de Chile, Santiago, Chile

Mougeot LJA (2006) Growing better cities. Urban agriculture for sustainable development. IDRC, Canada

Mundial B (2012) CO2 Emmission Data. Base, World Bank Data

Murdoch J, Abram S (1998) Defining the limits of community governance. J Rural Stud 14(1):41-50

Naredo JM, García Zaldívar R (2008) Estudio sobre la ocupación del suelo por usos urbano-industriales, aplicado a la Comunidad de Madrid. Universidad Politécnica de Madrid y Ministerio de Medio. Ambiente, Madrid

OSE (2006) Anual Report of Sustainability in Spain. National Observatory for Sustainability, Alcalá de Henarés

Paul V, Tonts M (2005) Containing urban sprawl: trends in land use and spatial planning in the metropolitan region of Barcelona. J Environ Plan Manag 48(1):7-35

Plieninger T, Bieling C (2012) Resilience and the cultural landscape. understanding and managing change in human shape environment, Cambridge. Cambridge University Press, Cambridge 
Power AG (2010) Ecosystem services and agriculture: tradeoffs and synergies. Phil Trans R Soc B 365:2959-2971

Pretty J (2003) Social capital and the collective management of resources. Science 302(5652):1912-1914

Ritchie J, Spencer L (1994) Qualitative data analysis for applied policy research. In: Bryman A, Burgess RG (eds) Analyzing qualitative data. pp 173-194, B

Romano B (2002) Evaluation of urban fragmentation in the ecosystems, Proceedings of International Conference on Mountain Environment and Development (ICMED), ottobre 15-19 2002. Chengdu, China

Santos Y, Ganges L, Herrera Calvo PM, Rivas Sanz JL D I, Lalana Soto JL (2013) Bases conceptuales en la planificación espacial de cara a la protección ambiental y paisajística/New conceptual basis for spatial planning facing environmental and landscape protection. Ciudades 1:113-138

SENC (2004) Guía de la alimentación saludable. Sociedad Española de Nutrición Comunitaria, Madrid

Simon Rojo M, Moran Alonso N, Zazo Moratalla A, Rodriguez Alonso R (2012a) Urbanism and periurban agrarian ecosystems. International Seminar, Assessment of PAEc-SP Project Outcomes, Mairea, Madrid

Simon Rojo M, Zazo Moratalla A, Moran Alonso N (2012b) Nuevos enfoques de planificación territorial para re(con)ducir la vulnerabilidad de los espacios agrarios periurbanos. Ciudades 15:151-166

Staub C, Ott W et al (2011) Indicators for Ecosystem Goods and Services. Framework, methodology and recommendations for a welfare-related environmental reporting, Federal Office for the Environment, Bern. Environ Stud, pp 1102-17S

Swinton SM, Lupi F, Robertson GP, Hamilton SK (2007) Ecosystem services and agriculture: Cultivating agricultural ecosystems for diverse benefits. Ecol Econ 64(2):242-252

TEEB (2010) The economics of ecosystems and biodiversity ecological and economic foundations. Kumar P, Earthscan, London and Washington

UK National Ecosystem Assessment (2011) The UK national ecosystem assessment technical report. UNEP-WCMC, Cambridge

van Veenhuizen R, Danso G (2007) Profitability and sustainability of urban and periurban agriculture. $\mathrm{FAO}$, Rome

Villasante RT (2006) Desbordes creativos. Estilos y estrategias para la transformación social. La Catarata, Madrid

Villasante RT, Montañés M, Martí J (2000) La investigación social participativa. El Viejo Topo, Madrid

Voogd H, Woltjer J (1999) The communicative ideology in spatial planning: some critical reflections based on the Dutch experience. Environ Plann B 26(6):835-854

Williams NSG, McDonnell MJ, Seager EJ (2005) Factors influencing the loss of an endangered ecosystem in an urbanising landscape: a case study of native grasslands from Melbourne, Australia. Landsc Urban Plan 71(1):35-49

Wodak R (2004) Critical discourse analysis. In: Seale C, Gobo G, Gubrium JF, Silverman D (eds) Qualitative research practice. Concise Paperback Edition. Sage, London

Zasada I (2011) Multifunctional peri-urban agriculture - a review of societal demands and the provision of goods and services by farming. Land Use Policy 28(4):639-648

doi:10.1186/s13717-014-0013-x

Cite this article as: Simon Rojo et al:: Pathways towards the integration of periurban agrarian ecosystems into the spatial planning system. Ecological Processes 2014 3:13.

\section{Submit your manuscript to a SpringerOpen ${ }^{\circ}$ journal and benefit from:}

- Convenient online submission

- Rigorous peer review

- Immediate publication on acceptance

- Open access: articles freely available online

- High visibility within the field

- Retaining the copyright to your article

Submit your next manuscript at $\gg$ springeropen.com 